\title{
Clinical outcomes of xeno-free expansion and transplantation of autologous ocular surface epithelial stem cells via contact lens delivery: a prospective case series
}

\author{
Samantha Bobba ${ }^{1,4}$, Sharron Chow ${ }^{1}$, Stephanie Watson ${ }^{2,3,4}$ and Nick Di Girolamo ${ }^{1 *}$
}

\begin{abstract}
Introduction: Depletion of limbal stem cells leads to a debilitating condition known as limbal stem cell deficiency, characterised by impaired corneal wound healing and poor vision. The aim of this study was to determine whether delivering progenitor cells on a contact lens is a viable and effective alternative to current transplantation techniques, which are complicated by biological and xenogeneic materials.

Methods: Sixteen eyes of 16 patients who had total $(n=14)$ and partial $(n=2)$ limbal stem cell deficiency (chemical burns, five eyes; iatrogenic causes, four eyes; aniridia, three eyes; trachoma-induced, two eyes; contact lens over-wear, one eye; and cicatrising conjunctivitis, one eye) and who had failed prior therapy were recruited prospectively into the study. Autologous limbal $(n=7)$ or conjunctival epithelial $(n=9)$ biopsies were harvested from patients and placed on the concave surface of silicone hydrogel contact lenses. Cells were expanded in culture with autologous serum and transplanted onto the ocular surface.
\end{abstract}

Results: Restoration of a transparent avascular and clinically stable corneal epithelium was attained in 10 of 16 eyes (63\%) at a median follow-up time of 2.5 years (range of 0.8 to 5.8 years). Although minor complications occurred in two eyes of two patients because of contact lens insertion or removal, these were not associated with long-term sequelae.

Conclusions: This is the first and largest study to evaluate the mid-term outcomes of autologous limbal/conjunctival stem cell transplantation via a US Food and Drug Administration-approved contact lens, demonstrating that delivery of ocular progenitor cells via this procedure offers a viable, effective, and xeno-free alternative to current transplantation methodologies.

Trial registration: Australian New Zealand Clinical Trials Registry ACTRN012607000211460. Registered 17 April 2007.

\section{Introduction}

The corneal epithelium is maintained by stem cells (SCs) presumed to reside in the transitional zone between the cornea and conjunctiva, also known as the limbus [1]. Depletion of limbal epithelial stem cells (LESCs) through damage to their microenvironment (the niche) or aberrant functional modification can result in limbal stem cell deficiency (LSCD), a disease characterised by impaired corneal wound healing, loss of vision, and chronic pain [2].

\footnotetext{
* Correspondence: n.digirolamo@unsw.edu.au

${ }^{1}$ School of Medical Sciences, University of New South Wales, High Street, Kensington, Sydney 2052, Australia

Full list of author information is available at the end of the article
}

LSCD is classified as either partial (involving a sector) or total (affecting the entire cornea) and encompasses a range of aetiologies. Surgical treatment via keratoplasty is deemed ineffective as these patients lack the SCs needed to re-epithelialise their corneal surface.

Since the pioneering work of Kenyon and Tseng [3] (1989) on limbal tissue transplantation, the field has grown exponentially. Moreover, substantial research efforts have been devoted to developing carrier substrates that facilitate cell expansion ex vivo and integration during transplantation. To date, the most commonly used substrate for LESC transplantation is human amniotic membrane (HAM), and reported success rates in patients with LSCD range from

\section{Ciomed Central}

(c) 2015 Bobba et al.; licensee BioMed Central. This is an Open Access article distributed under the terms of the Creative Commons Attribution License (http://creativecommons.org/licenses/by/4.0), which permits unrestricted use, distribution, and reproduction in any medium, provided the original work is properly credited. The Creative Commons Public Domain Dedication waiver (http://creativecommons.org/publicdomain/zero/1.0/) applies to the data made available in this article unless otherwise stated. 
$46 \%$ to $100 \%$ [4-6]. Although HAM is non-immunogenic, anti-angiogenic and contains SC support factors, its disadvantages include its semi-opaqueness, donor-to-donor variability, expensive screening, and strict guidelines for preparation and storage [7-9]. Fibrin has been trialed as an alternative carrier; however, its short setting time poses difficulties in manipulating the membrane film during surgery $[10,11]$. Several other biomaterials have been trialed in ex vivo or animal models, or both, albeit to differing degrees. These scaffolds include silk fibroin [12,13], collagen shields [14], anterior human lens capsule [15], and silicone hydrogen contact lenses (CLs) [16-18]. Recent studies have shown that cells labeled ex vivo can adhere to CLs and are able to successfully transfer, survive, and proliferate after delivery $[19,20]$. Moreover, our clinical trial using this system showed that CLs could be used as a carrier and substrate for in vivo delivery of ocular surface cells, with a $100 \%$ success rate recorded in three patients with LSCD 12 months after the procedure [21]. Since we first reported our technique, biodegradable membranes which eliminate the need to remove the carrier have also been developed; however, they are still in the preliminary stages of trialing [22]. Advantages of CLs as a substrate include its transparency, mechanical stability, cost-effectiveness, and non-immunogenic nature. Currently, comparisons between different transplantation methodologies for managing LSCD are lacking and there is an increasing need for xeno-free expansion to meet the increasingly strict regulatory demands. Herein, we report the short- to mid-term outcomes of using CLs for xeno-free culture and expansion and as a carrier for ocular surface SC transplantation in 16 patients with LSCD.

\section{Methods}

\section{Clinical trial}

The clinical trial was registered in Australia (ACTRN012607000211460) and approved by the South Eastern Sydney Local Health District Human Research Ethics Committee (SESLHD HREC-07/025). The SESLHD Executive Committee approved the follow-up arm of the trial (HREC13/139). All components of this study were carried out in accordance with the Declaration of Helsinki. The protocol for using human cells and tissue was approved by the University of New South Wales Human Research Ethics Committee (HREC-06290). Informed consent was obtained from all patients.

\section{Patients with limbal stem cell deficiency}

The study design was a prospective non-comparative case series comprising a sample size of 16 eyes from 16 patients with LSCD who had failed prior therapy. Patients were recruited between 2007 and 2011 and were referrals to the Corneal Unit at the Sydney Eye Hospital (Sydney, Australia), Eye Clinic at the Prince of Wales Hospital (Randwick, Sydney, Australia), or private rooms (Bondi
Junction, Sydney). Patients with severe total or partial LSCD were included in the study, and LSCD was diagnosed clinically $[10,23]$. Clinical features that distinguished these patients included recurrent or persistent epithelial defects, corneal fibrovascular pannus, and chronic inflammation $[10,23]$. For partial LSCD, patients had failed all prior medical therapy and had at least 6 clock hours (180 degrees) of whorl-like epitheliopathy, opaque epithelium arising from the limbus, and superficial neovascularisation or conjunctivalisation or both $[24,25]$. Photographs were taken to document these features. Impression cytology was not performed as it can induce painful persistent epithelial defects with the risk of infection or increased inflammation or both [10]. Patients with total or partial LSCD were included if they had failed all prior therapy, which included autologous serum drops, preservative-free lubricants, therapeutic CL wear, limbal tissue allografts, HAM transplants, superficial keratectomy, and conventional corneal grafts. Table 1 summarises the baseline demographic features of our patients.

\section{Cell culture, contact lens insertion, and post-operative follow-up}

Multiple (two or three) autologous epithelial biopsies (approximately equal to 1 to $2 \mathrm{~mm}^{2}$ ) were taken from either the superior limbal region or superior conjunctival fornix of the contralateral eye under local anesthesia (Minims Tetracaine Hydrochloride 1\%; Chauvin Pharmaceuticals, Bausch \& Lomb, Kingston-Upon-Thames, UK) based on data suggesting that cells from the superior forniceal explants grow more effectively [26,27]. Serum was isolated from $20 \mathrm{~mL}$ of whole blood taken at the time of biopsy by standard venipuncture. Each biopsy was placed on the concave surface of a siloxane-hydrogel extended-wear CL (Lotrafilcon A; CIBA Vision, Duluth, GA, USA) in 24-well culture plates (Corning Inc., Corning, NY, USA) in Eagle's minimum essential medium containing 10\% autologous serum with antibiotic supplements as previously detailed [16,21]. Cultures were kept in an isolated incubator set to $37^{\circ} \mathrm{C}$ with $5 \% \mathrm{CO}_{2}$, and growth was monitored daily with media changed on alternate days. When cells reached confluence ( 9 to 16 days), patients were scheduled for the procedure and the cell-coated CL transported to the operating theatre in growth media in cold storage $\left(4^{\circ} \mathrm{C}\right.$ to $\left.10^{\circ} \mathrm{C}\right)$. This ensured that cell activity could be preserved in the event of delays in theatres. Cells emerging from tissues explanted on CLs have previously been phenotyped and shown to express several key ocular surface SC markers [21].

Patients with unilateral conditions had limbal and conjunctival biopsies harvested from separate sites, and patients with bilateral disease received cells from conjunctival biopsies. In patients with unilateral conditions, limbal biopsies were cultured on CLs; however, two patients (cases 5 and 15) had limbal biopsies that did not grow. Thus, these 
Table 1 Patient demographics and pre-operative characteristics

\begin{tabular}{|c|c|c|c|c|c|c|c|c|}
\hline $\begin{array}{l}\text { Case. age at last } \\
\text { follow-up,years/Sex }\end{array}$ & $\begin{array}{l}\text { Eye, } \\
\text { R/L }\end{array}$ & $\begin{array}{l}\text { LSCD, } \\
\text { unilateral/bilateral }\end{array}$ & $\begin{array}{l}\text { Days in } \\
\text { culture }\end{array}$ & $\begin{array}{l}\text { LSCD, } \\
\text { partial/total }\end{array}$ & Aetiology of LSCD & Previous procedures & $\begin{array}{l}\text { Post-operative } \\
\text { topical therapy }\end{array}$ & $\begin{array}{l}\text { Post-operative } \\
\text { immunosuppressive or } \\
\text { systemic ocular therapy or both }\end{array}$ \\
\hline 1. $40 / \mathrm{M}$ & $\mathrm{R}$ & B & 14 & $\mathrm{~T}$ & Aniridia & $\begin{array}{l}\text { Limbal tissue allograft }+S K^{*} \text {, } \\
\text { CE/IOL }\end{array}$ & $\begin{array}{l}\text { FML, cellufresh tears, } \\
\text { timolol }\end{array}$ & $\begin{array}{l}\text { Minocycline } 50 \text { mg, } \\
\text { mycophenolate mofetil } 500 \text { mg } \\
\text { BD }\end{array}$ \\
\hline 2. $77 / F$ & R & U & 10 & $\mathrm{~T}$ & $\begin{array}{l}\text { Primary acquired melanosis; } \\
\text { multiple surgeries/topical } \\
\text { mitomycin C therapy }\end{array}$ & $\begin{array}{l}\text { Multiple conjunctival } \\
\text { excisions }\end{array}$ & Predsol minims & Nil \\
\hline 3. $73 / F$ & R & U & 10 & $\mathrm{~T}$ & $\begin{array}{l}\text { Recurrent melanoma; multiple } \\
\text { surgeries }\end{array}$ & $\begin{array}{l}\text { Multiple conjunctival } \\
\text { excisions, cryotherapy, lid } \\
\text { repair, HAM transplant }\end{array}$ & $\begin{array}{l}\text { Cellufresh tears, dexa } \\
\text { minims }\end{array}$ & Nil \\
\hline 4. $68 / \mathrm{M}$ & L & B & 11 & $P$ & Query trachoma-induced & Ptosis repair & $\begin{array}{l}\text { Cellufresh tears, dexa } \\
\text { minims }\end{array}$ & Nil \\
\hline 5. $61 / \mathrm{M}$ & $\mathrm{R}$ & U & 9 & $\mathrm{~T}$ & Chemical burn & Limbal tissue allograft* & Dexa minims & Doxcycline 100 mg \\
\hline $6.65 / F$ & R & B & 16 & $\mathrm{~T}$ & Aniridia & 2xPK*, cyclodiode laser & Dexa minims, timolol & Nil \\
\hline 7. $33 / \mathrm{M}$ & L & U & 14 & $\mathrm{~T}$ & Chemical burn & $\begin{array}{l}\text { HAM transplant + nexagon } \\
\text { application* }\end{array}$ & Dexa minims & Nil \\
\hline 8. $50 / \mathrm{M}$ & L & U & 14 & $\mathrm{~T}$ & Chemical burn & $\begin{array}{l}\text { Ptosis repair, } \mathrm{PK}^{*} \text {, limbal } \\
\text { tissue allograft + } \mathrm{PK}^{*}, \mathrm{CE} / \\
\mathrm{IOL}\end{array}$ & $\begin{array}{l}\text { Dexa minims, atropine } \\
\text { sulphate } 1 \% \text { minims }\end{array}$ & $\begin{array}{l}\text { Prednisone } 80 \mathrm{mg} \text { in a tapering } \\
\text { regime }\end{array}$ \\
\hline 9. 52/M & R & U & 14 & $P$ & Query trachoma-induced & $\begin{array}{l}\text { Removal of } \\
\text { pseudopterygium }\end{array}$ & Dexa minims & Nil \\
\hline 10. $72 / F$ & L & B & 14 & $\mathrm{~T}$ & Aniridia & $\begin{array}{l}\text { CE/IOL, ectropion repair, } \\
\text { EDTA }\end{array}$ & $\begin{array}{l}\text { Bimatoprost } 0.03 \% \text {, } \\
\text { minims pilocarpine nitrate } \\
2 \% \text {, refresh tears }\end{array}$ & Acetazolamide $125 \mathrm{mg} \mathrm{BD}$ \\
\hline 11. $62 / \mathrm{M}$ & $R$ & B & 15 & $\mathrm{~T}$ & Multiple surgeries & $\begin{array}{l}\text { PTK, PK (for corneal ectasia), } \\
\text { CE/IOL }\end{array}$ & Dexa minims & Nil \\
\hline 12. $81 / \mathrm{M}$ & L & U & 14 & $\mathrm{~T}$ & Chemical burn & $\mathrm{Nil}$ & $\begin{array}{l}\text { Atropine sulphate } 1 \% \\
\text { minims, timolol/ } \\
\text { latanoprost, dexa minims }\end{array}$ & Nil \\
\hline 13. $28 / \mathrm{M}$ & R & U & 9 & $\mathrm{~T}$ & Chemical burn & BV diathermy & Dexa minims & Nil \\
\hline 14. $65 / F$ & L & B & 16 & $\mathrm{~T}$ & $\mathrm{CL}$ over-wear & $\begin{array}{l}\mathrm{PK}^{*}, \mathrm{CE} / \mathrm{IOL}, \mathrm{PK}+\text { limbal } \\
\text { tissue allograft* }+ \\
\text { tarsorrhaphy, DSEK }\end{array}$ & $\begin{array}{l}\text { Predsol minims, } \\
\text { latanoprost/timolol, } \\
\text { atropine sulphate 1\% } \\
\text { minims }\end{array}$ & Nil \\
\hline 15. $85 / \mathrm{M}$ & $R$ & U & 14 & $P$ & $\begin{array}{l}\text { Limbal tumor excision; limbal } \\
\text { surgeries }\end{array}$ & CE/IOL & Dexa minims, FML & Nil \\
\hline
\end{tabular}


Table 1 Patient demographics and pre-operative characteristics (Continued)

16. 80/F R B $\quad 9 \quad T \quad$ Cicatrising conjunctivitis:

ocular sur

CE/IOL, blepharoplasty

Dexa minims, cellufresh

tears, timolol/latanoprost glaucoma medication

All patients were additionally prescribed minims chloramphenicol 0.5\% post-operatively (not included in table). Asterisk (*) indicates previous surgical procedures to treat limbal stem cell deficiency (LSCD). Days in culture refers to the time to establish a reasonable number of cells on the contact lens before transplantation. BD, twice daily dosing; BV, blood vessel; CE/IOL, cataracts extraction/intraocular lens insertion; cellufresh tears, preservative free carboxymethylcellulose sodium $5 \mathrm{mg} / \mathrm{mL}$; CL, contact lens; dexa minims, minims dexamethasone sodium phosphate $0.1 \%$; DSEK, Descemet's stripping endothelial keratoplasty; EDTA,

ethylenediaminetetraacetic acid chelation therapy for band keratopathy; FML, flurometholone 1\%; HAM, human amniotic membrane; PK, penetrating keratoplasty; predsol minims, minims prednisolone sodium phosphate $0.5 \%$; PTK, phototherapuetic keratectomy;refresh tears, preservative free polyvinyl alcohol 1.4\%; SK, superficial keratectomy 
patients received ocular progenitor cells from conjunctival biopsies to avoid the risk of SC failure in the donor eye being induced by a repeat limbal biopsy.

Prior to insertion of the CL, $5 \%$ betadine was applied to the eye and a total superficial keratectomy, including removal of limbal epithelium, was performed to remove any irregular epithelium or pannus or both [21]. The CL with biopsy and expanding cells was inserted onto the patient's ocular surface under topical anesthesia (Minims Benoxinate Hydrochloride 0.4\%; Chauvin Pharmaceuticals, Bausch \& Lomb). Penetrating keratoplasty (PK) was performed prior to $\mathrm{CL}$ insertion as indicated in patients who had endothelial failure with stromal edema (cases 6, 8, and 14) and stromal scarring (case 12) reducing vision. Post-operatively, patients continued to take prior systemic and topical therapy. For prophylaxis against infection, each patient was prescribed Minims Chloramphenicol 0.5\% (Chauvin Pharmaceuticals, Bausch \& Lomb), which was applied for 4 weeks. Twelve patients also received Minims Dexamethasone sodium phosphate $0.1 \%$ (Chauvin Pharmaceuticals, Bausch \& Lomb) tapered over the course of 1 month. Two patients were continued on Minims Prednisolone sodium phosphate 0.5\% (Chauvin Pharmaceuticals, Bausch \& Lomb) (Table 1). The topical steroid regime was determined by the treating physician according to the degree of postoperative inflammation.

\section{Follow-up and assessment of outcome}

Ophthalmological evaluations after the procedure were performed at days 1 and 7 and then at 1, 3, 6, and 9 months. Six-month follow-ups were scheduled during the following year and yearly visits thereafter. Each visit involved taking a medical history, recording ocular symptoms, imaging the eye, and performing Snellen's test for best-corrected visual acuity (BCVA), slit-lamp examination, tear film assessment, ocular surface staining with fluorescein, and tonometry. Patients' medical records were reviewed, and data were recorded on a proforma and entered into an electronic database. Success was defined as ocular surface stability and visual improvement unless otherwise limited by preexisting or concomitant disease. Two authors (SW and SB) determined ocular surface stability from clinical examination, clinical photographs, and medical notes. Independent grading of each patient was also performed from clinical photographs by author ND. In alignment with previously published reports $[4,14,23,28]$, restoration of corneal epithelium, reduction of neovascularisation, and the absence of recurrent or persistent epithelial defects (PEDs) were the parameters used to determine ocular surface stability. Corneal epithelialisation was defined on the basis of transparency without epithelial defects on slit-lamp examination and the absence of abnormally high fluorescein permeability. Partial success was defined as improvements in subjective ocular symptoms or BCVA or both with a stable central corneal epithelium and no PEDs despite the presence of peripheral epithelial whorl-staining or recurrent vascularisation, even if not as extensive as at the time of admission [14]. Treatment failure was defined as recurrence of LESC failure with conjunctivalisation of the ocular surface.

\section{Statistical analysis}

Survival probability of grafts was analyzed by KaplanMeier and the log-rank test. Graft survival began at the time of transplant, and an event was defined as failure or success at the last follow-up. Descriptive statistics were used to summarise all continuous and categorical variables. Analyses were performed by SPSS 21.0 software (IBM SPSS Statistics, version 21; IBM Corporation, Armonk, NY, USA).

\section{Results}

\section{Cell culture and growth of biopsies}

Cells began to emerge as early as 2 days in culture irrespectively of whether limbal or conjunctival tissue biopsies were used (Figure 1A and B). Eventually, a halo of cells of similar morphology surrounded each limbal or conjunctival biopsy, and the migratory front of expanding cells reached the edge of the CL by 9 to 16 days post-explanting (Figure 1C-E). In four (25\%) out of 16 patients, a second set of biopsies was harvested for culture purposes as insufficient growth developed from the first. No signs of SC failure were observed in any donor eye. No other complications were noted in regard to the culture component. Prior to transplantation, an aliquot of media from each culture was tested for mycoplasma contamination; however, none returned a positive reading (Figure 1F).

\section{Patient characteristics}

Sixteen eyes from 16 patients were enrolled in the study between 2007 and 2011. The mean age at follow-up was $62 \pm$ 17 years (range of 28 to 85), and the male-to-female ratio was 10:6. Table 2 summarises the post-operative characteristics and outcomes of patients enrolled in the trial. The most common aetiologies were chemical burns (31\%), iatrogenic causes (25\%), and aniridia (19\%). Other underlying aetiologies were trachoma-induced LSCD (cases 4 and 9), CL over-wear (case 14), and cicatrising conjunctivitis due to ocular surface toxicity from glaucoma medications (case 16).

\section{Ocular surface stability}

Restoration of ocular surface stability was seen in 12 eyes (75\%) at 1 year and 11 eyes (69\%) at 2 years with a cumulative survival of $63 \%$ after a median follow-up time of $2.5 \pm$ 1.2 years (range of 0.8 to 5.8 ) (Figures $2 \mathrm{~A}$ and $3 \mathrm{~A}$ and $\mathrm{B}$ ). Biopsies of conjunctival origin had a higher cumulative survival $(78 \%)$ compared with the survival rate displayed by limbal biopsies (43\%); however, this was not a statistically 

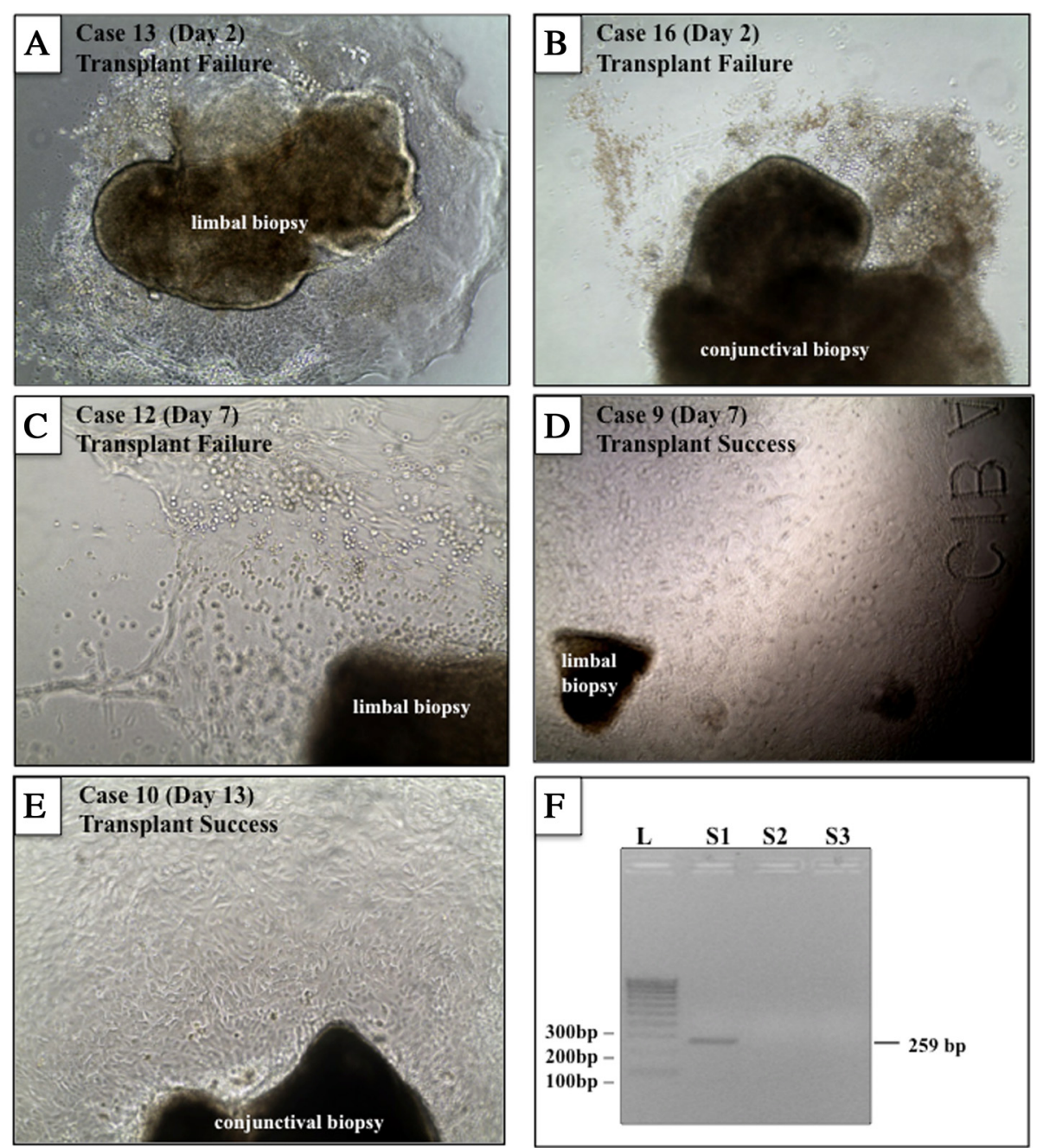

Figure 1 Cell growth from limbal and conjunctival biopsies. Phase-contrast images of limbal (A, C, D) and conjunctival (B, E) biopsies excised from patients with limbal stem cell deficiency and cultured over a specific period (see panel label for case identification number and time in culture). Although cultures displayed ample proliferation activity, some grafts failed (A-C) whereas others were successful (D and E) at last follow-up. A representative polymerase chain reaction for mycoplasma (F) on conditioned media derived from cultured cells from patient 12 (S2) is shown. S1 (positive control) shows a band at 259 base pairs (bp), and S3 is a negative control.

significant difference as assessed by the log-rank test (Figure 2B, $P=0.06$ ). The outcomes of three of these patients (cases 1 to 3 ) at the 1-year follow-up were published previously [20], and all continue to maintain a stable ocular surface at the 5- to 6-year follow-up. Case 1, though still with visual improvement from baseline, has recently developed central subepithelial scarring and increasing epithelial irregularity. A small area of localised inferonasal band keratopathy adjacent to the limbus developed in case 2, with endothelial decompensation, and has occasionally developed local ulceration associated with the band keratopathy. One eye (case 14) was deemed a partial success, having achieved a transparent central corneal epithelium with no recurrent ulcers or PEDs or both, complete resolution of ocular pain, and improved visual acuity (hand movements to 6/90). This was despite a localised region (fewer than 2 clock-hours) of superior-temporal whorl-like corneal staining, which remained stable at the 2-year follow-up period (Figure $3 \mathrm{C}$ and D). When analysed according to the aetiology of LSCD, patients with iatrogenic causes experienced a $100 \%$ success rate (four out of four cases) compared with a $20 \%$ success (one out of five cases) for patients with chemical burns. Aniridia was associated with a $67 \%$ success rate (two out of three cases), and patients with trachoma were both deemed successful. When analysed according to the severity of LSCD, the three patients with partial LSCD experienced a $100 \%$ success rate and the patients with total LSCD experienced a $54 \%$ success rate.

\section{Visual acuity and ocular symptoms}

In $90 \%$ of patients deemed successes or partial successes, ocular symptoms (pain, burning, and photophobia) resolved 
Table 2 Post-operative characteristics and outcomes of ocular surface stem cell transplantation via contact lens delivery

\begin{tabular}{|c|c|c|c|c|c|c|c|c|c|c|}
\hline Case & $\begin{array}{l}\text { Type of } \\
\text { graft }\end{array}$ & $\begin{array}{l}\text { Follow-up, } \\
\text { years }\end{array}$ & $\begin{array}{l}\text { Complications } \\
\text { during cell culture }\end{array}$ & $\begin{array}{l}\text { Procedure } \\
\text { performed in trial }\end{array}$ & $\begin{array}{l}\text { Subsequent } \\
\text { procedures }\end{array}$ & $\begin{array}{l}\text { Pre-operative } \\
\text { visual acuity }\end{array}$ & $\begin{array}{l}\text { Post-operative } \\
\text { visual acuity }\end{array}$ & Ocular surface & Notes & Result \\
\hline 1 & $\mathrm{C}$ & 5.75 & $\begin{array}{l}\mathrm{CL} \text { rolled under } \\
\text { superior lid, } \\
\text { required insertion } \\
\text { of second } \mathrm{CL}\end{array}$ & $\mathrm{SCT}+\mathrm{SK}$ & - & $6 / 60+1$ & $6 / 45$ & Central clear, peripheral pannus & $\begin{array}{l}\text { Glaucoma, DE, } \\
\text { subepithelial scarring }\end{array}$ & $\mathrm{s}$ \\
\hline 2 & L & 5.67 & $\begin{array}{l}\text { biopsy retained in } \\
\text { cornea }\end{array}$ & $\mathrm{SCT}+\mathrm{SK}$ & $\begin{array}{l}\text { DSEK (endothelial } \\
\text { decompensation), CE/ } \\
\text { IOL }\end{array}$ & $6 / 18-1$ & $6 / 60$ & $\begin{array}{l}\text { Central clear, peripheral } \\
\text { vascularisation }\end{array}$ & $\begin{array}{l}\text { Endothelial } \\
\text { decompensation }\end{array}$ & S \\
\hline 3 & L & 5.33 & Nil & $\mathrm{SCT}+\mathrm{SK}$ & - & CF at $0.2 \mathrm{~m}$ & LP & $\begin{array}{l}\text { Central clear, peripheral } \\
\text { vascularisation }\end{array}$ & $\begin{array}{l}\text { Stromal scarring, corneal } \\
\text { stromal opacity, } \\
\text { cataracts }\end{array}$ & s \\
\hline 4 & C & $\begin{array}{l}2.92 \text { (lost } \\
\text { to follow- } \\
\text { up) }\end{array}$ & Nil & $\mathrm{SCT}+\mathrm{SK}$ & - & $6 / 45$ & $6 / 36$ & $\begin{array}{l}\text { Central clear, superior peripheral } \\
\text { pannus }\end{array}$ & Subepithelial scarring & $S$ \\
\hline 5 & C & 4.67 & $\begin{array}{l}\text { Second biopsy, no/ } \\
\text { poor growth }\end{array}$ & $S C T+S K$ & - & CF at $0.5 \mathrm{~m}$ & $1 / 60$ & Central clear, peripheral pannus & Stromal scarring & $\mathrm{s}$ \\
\hline 6 & C & 4.17 & $\begin{array}{l}\text { Second biopsy, no/ } \\
\text { poor growth }\end{array}$ & $\mathrm{SCT}+\mathrm{PK}$ & $\begin{array}{l}\text { PK + HAM graft (failed } \\
\text { transplant), } \\
\text { blepharoplasty, CE/IOL, } \\
\text { Molteno implant }\end{array}$ & $\mathrm{HM}$ & $6 / 60$ & PED & $\begin{array}{l}\text { Corneal astigmatism, } \\
\text { glaucoma, DE }\end{array}$ & $\mathrm{F}$ \\
\hline 7 & $\mathrm{~L}$ & 3.25 & $\begin{array}{l}\text { Second biopsy, no/ } \\
\text { poor growth }\end{array}$ & $\mathrm{SCT}+\mathrm{SK}$ & - & CF at $1 \mathrm{~m}$ & CF at $1 \mathrm{~m}$ & $\begin{array}{l}\text { PED, recurrent corneal } \\
\text { vascularisation }\end{array}$ & Subepithelial scarring & $\mathrm{F}$ \\
\hline 8 & $\mathrm{~L}$ & 2.58 & Nil & $\mathrm{SCT}+\mathrm{PK}$ & YAG & $\mathrm{HM}$ & $0.5 / 60$ & PED & $\begin{array}{l}\text { Graft astigmatism, } \\
\text { stromal scarring }\end{array}$ & $\mathrm{F}$ \\
\hline 9 & L & 0.75 & $\begin{array}{l}\text { Small defect } \\
\text { created on removal } \\
\text { of } C L\end{array}$ & $\mathrm{SCT}+\mathrm{SK}$ & - & $6 / 6$ & $6 / 6$ & Central clear & $\begin{array}{l}\text { Corneal astigmatism, } \\
\text { subepithelial scarring }\end{array}$ & S \\
\hline 10 & C & 2.42 & Nil & $\mathrm{SCT}+\mathrm{SK}$ & - & CF at $2 \mathrm{~m}$ & $6 / 90$ & $\begin{array}{l}\text { Central clear, ulcers from } \\
\text { toxicity of glaucoma meds }\end{array}$ & $\begin{array}{l}\text { DE, severe glaucoma, } \\
\text { progressive corneal } \\
\text { oedema, stromal } \\
\text { scarring }\end{array}$ & S \\
\hline 11 & C & 2.17 & Nil & $\begin{array}{l}\mathrm{SCT}+\mathrm{SK}+\mathrm{EDTA}+ \\
\mathrm{BV} \text { diathermy }\end{array}$ & - & $2 / 60$ & $1.5 / 60$ & $\begin{array}{l}\text { Central clear, pannus to graft- } \\
\text { host junction }\end{array}$ & $\begin{array}{l}\text { DE, postoperative } \\
\text { endophthalmitis (prior } \\
\text { PTK), corneal ectasia, } \\
\text { subep scarring }\end{array}$ & S \\
\hline 12 & L & 2.25 & $\begin{array}{l}\text { Second biopsy, no/ } \\
\text { poor growth }\end{array}$ & $\mathrm{SCT}+\mathrm{PK}+\mathrm{CE} / \mathrm{IOL}$ & - & $3 / 60$ & CF & $\begin{array}{l}\text { Irregular epithelium, graft } \\
\text { opacity, PEEs, PEDx2 on graft }\end{array}$ & $\begin{array}{l}\mathrm{DE} \text {, glaucoma, ocular } \\
\text { surface toxicity, stromal } \\
\text { scarring }\end{array}$ & $\mathrm{F}$ \\
\hline 13 & L & 2 & Nil & SCT & $\begin{array}{l}\text { HAM transplant } \\
\text { (corneal ulcer) }+ \\
\text { tarsorrhaphy, PK } \\
\text { (corneal perforation) }\end{array}$ & $\mathrm{HM}$ & $\mathrm{HM}$ & $\begin{array}{l}\text { Swirled epithelium, PED, } \\
\text { recurrent corneal vascularisation }\end{array}$ & Stromal scarring & $\mathrm{F}$ \\
\hline
\end{tabular}


Table 2 Post-operative characteristics and outcomes of ocular surface stem cell transplantation via contact lens delivery (Continued)

$14 \mathrm{C} 1.92 \quad \mathrm{Nil}$ SCT+PK HM 6/90 Central clear, mild subepithelial

$14 \mathrm{C}$

$1.92 \quad \mathrm{Nil}$

$\mathrm{SCT}+\mathrm{PK}$

Central clear, mild subepitheila

haze, $<2$ clock hours of

$\mathrm{DE}$, graft astigmatism

PS

superior-temporal whorl-like corneal staining

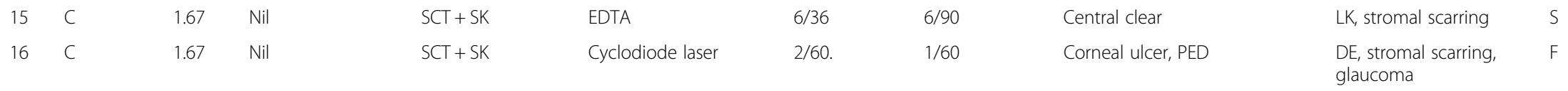

BV, blood vessel; C, conjunctival; CE/IOL, cataract extraction/intraocular lens; CF, counting fingers; CL, contact lens; DE, dry eye; DSEK, Descemet's stripping endothelial keratoplasty; EDTA, ethylenediaminetetraacetic acid chelation therapy for band keratopathy; F, failure; HAM, human amniotic membrane; HM, hand movements; L, limbal; LK, lipid keratopathy; LP, light perception; PED, persistent epithelial defect; PEEs, punctate epithelial erosions; PK, penetrating keratoplasty; PS, partial success; PTK, phototherapuetic keratectomy; S, success; SCT, stem cell transplant; SK, superficial keratectomy; YAG, yttrium aluminium garnet capsulotomy. 


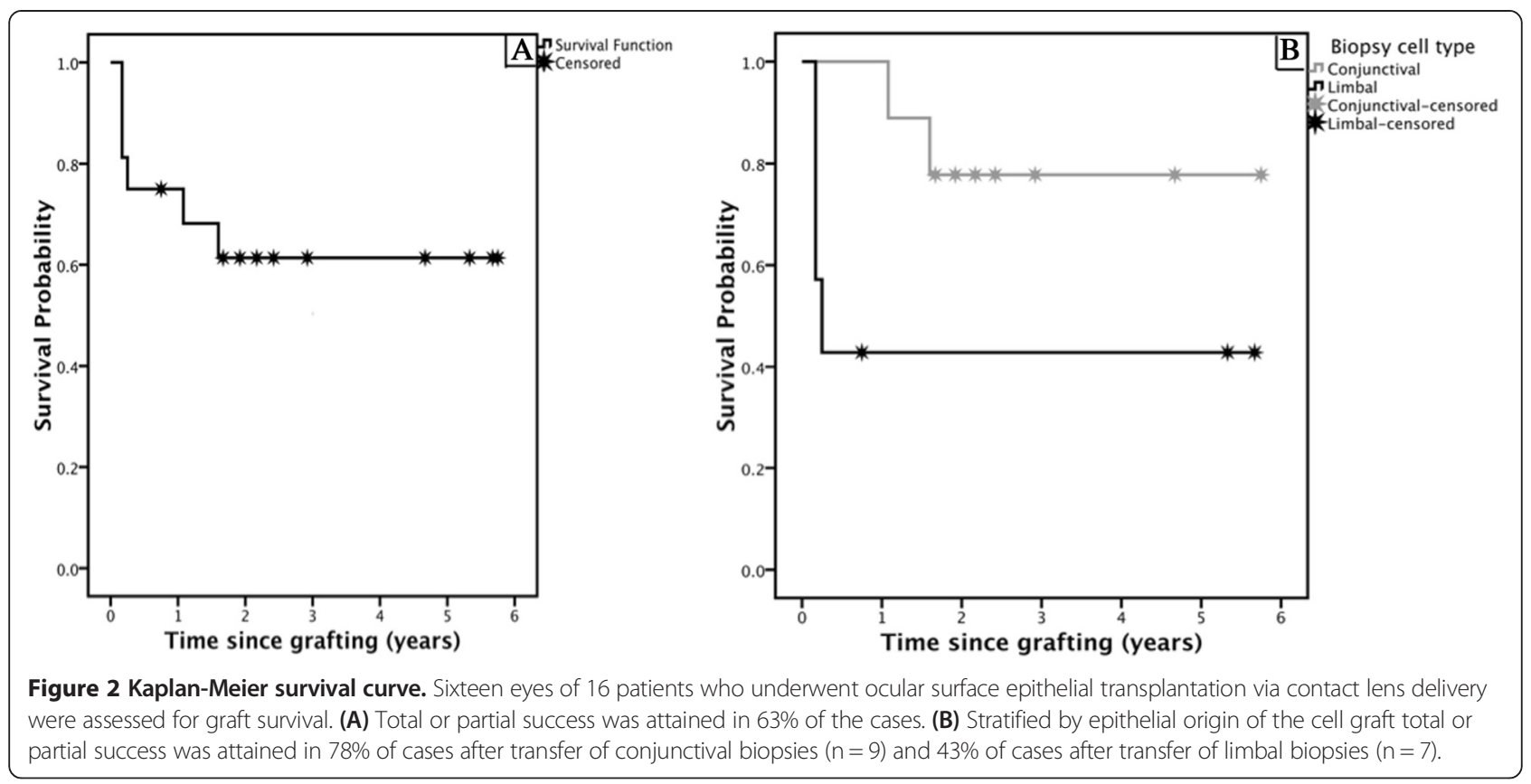

completely. Pre-existing corneal scarring or concomitant ocular disease limited visual improvement in most patients (Table 2). Fifty percent of patients who achieved a successful outcome attained improved visual acuity (at least one line) and the biopsies in each of these five patients were all of conjunctival origin. Twenty percent maintained their preoperative visual acuity (for example, patient 9 maintained a BCVA of 6 out of 6 after receiving cells from a limbal biopsy, and patient 11 maintained a BCVA of 2 out of 60 after a conjunctival biopsy). Thirty percent of the patients deemed successes experienced a decline in BCVA by 4,3 , and 1 line (cases 2, 15, and 3, respectively). The BCVA of patient 2 declined 3 years after SC transplantation because of endothelial decompensation and was subsequently treated with Descemet's stripping endothelial keratoplasty (DSEK). The decline in visual acuity of patient 3 was attributed to progressive cataract (untreated because of patient preference and corneal scarring limiting visual potential), and patient 15 to lipid keratopathy. Though deemed failures due to recurrence of epithelial defects, patients 6 and 8 both achieved improvements in their BCVA attributed to successful treatment of concomitant ocular disease (Table 2). By excluding these patients with confounding co-morbidities from analysis, we demonstrated that $71 \%$ of the remaining seven patients with a conjunctival biopsy had an improved BCVA and that $33 \%$ had a stable BCVA. This compares favourably with $75 \%$ of the remaining four patients with limbal biopsies having a stable BCVA and 25\% a reduced BCVA.

\section{Characteristics of failed transplants}

Failed transplants were characterised by recurrence of conjunctivalisation, vascularisation, corneal epithelial defects or a combination of these (Figure 3F and $\mathrm{H}$ ). Of the failures, the underlying aetiology was chemical burns in $67 \%$ (four out of six cases), and aniridia and cicatrising conjunctivitis were the cause in the other two patients. Of the failures, $50 \%$ had a second set of biopsies harvested prior to the cell transfer therapy because of insufficient growth from the first explants. In $67 \%$ of failures, biopsies were of limbal rather than conjunctival origin. Most failures (67\%) occurred within the first 4 months after transplantation; two eyes (cases 6 and 16) failed in the following 1 to 2 years, both complicated by ocular surface toxicity due to glaucoma medications. Fifty percent of the failures had prior grafts (to treat LSCD) that had also failed.

\section{Discussion}

This study found that transplantation of autologous limbal and conjunctival epithelial cells via CL delivery successfully restored the ocular surface in 63\% (10 out of 16 cases) of patients with LSCD at a median follow-up time of $2.5 \pm 1.2$ years (range of 0.8 to 5.8 ). The reported success rate of cultivated autologous limbal epithelial cell transplantation (LSCT) ranges from 33\% to $100 \%$ with a mean of $75 \%$ at 2-year follow-up [4,6,10,23,28-31]. Although our results were lower than the overall mean success rate $[4,6]$, they are within the range reported by others [4,6,10,23,28-31]. Furthermore, recent clinical trials $[10,32]$ have shown that repeat autologous cultivated LSCT following failed primary transplantation surgery successfully replenishes the ocular surface. As our technique is repeatable, a second cell transfer via CL in failed transplants could also increase the success rate of our technique in future studies. The variability in results from 

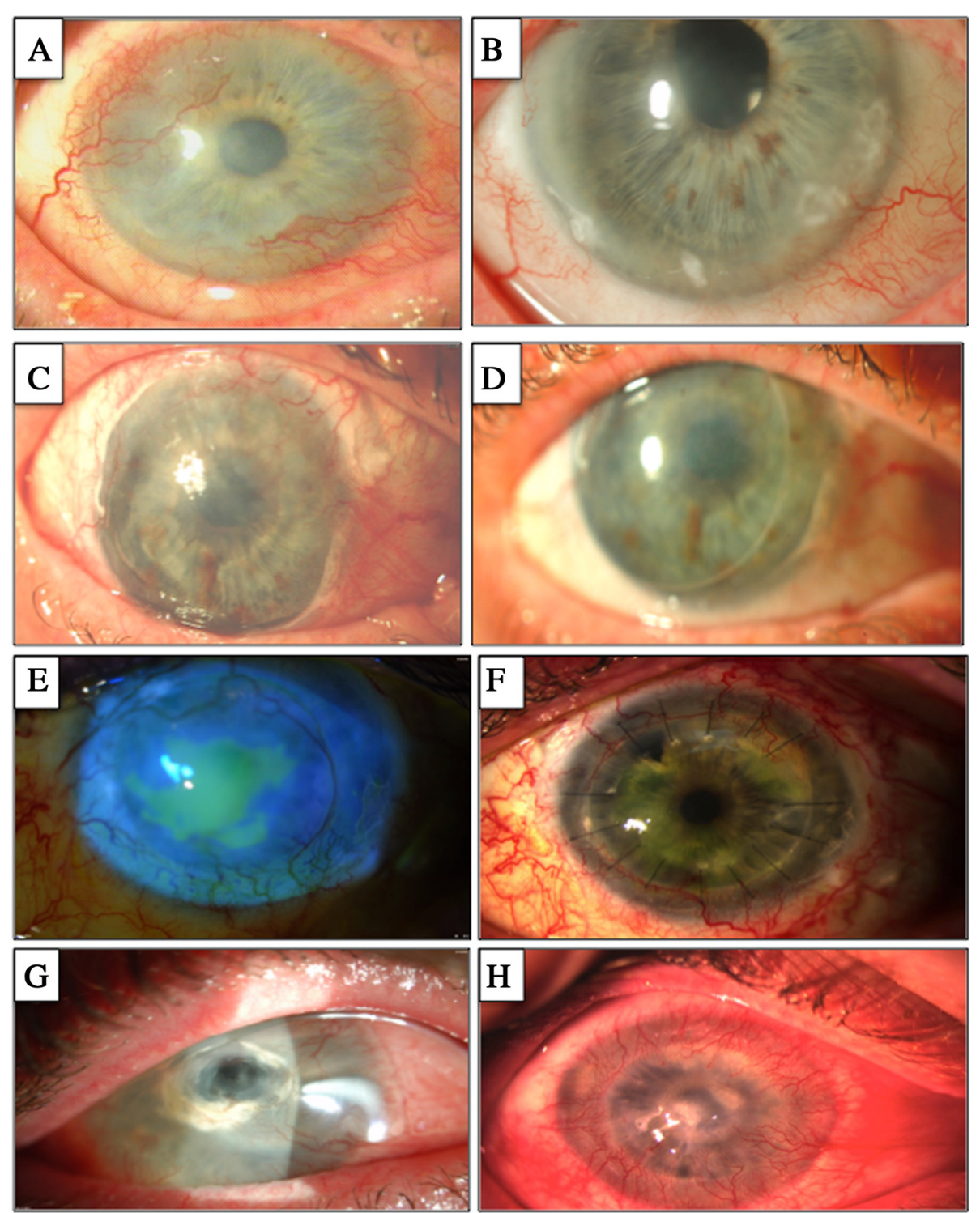

Figure 3 Clinical features of patients who underwent cell transplantation. Slit-lamp photographs of successful transplants in patient 2 (A, B) and patient $14(\mathbf{C}, \mathbf{D})$ before treatment (A, C) and at last follow-up - (B) 5.6 years and (D) 1.9 years - with restoration of an intact transparent corneal epithelium and reduced vascularisation (B). Notably, a localised region of superior-temporal whorl-like staining (obscured by the eyelid) was evident on clinical examination in patient 14 (D). Slit-lamp photographs of failed transplants in patient $8(\mathbf{E}, \mathbf{F})$ and patient $13(\mathbf{G}, \mathbf{H})$ before treatment $(\mathbf{E}, \mathbf{G})$ and at last follow-up-(F) 2.6 years and (H) 2 years - with an irregular corneal epithelium and recurrence of epithelial defects.

trial to trial could be attributed to patient selection and pre-operative condition; the majority of patients in our study failed all prior treatment regimens, including corneal grafts and limbal tissue transplants, and some even had coexistent ocular disease.

Although autologous limbal epithelial biopsies are the tissue of choice when expanding SCs for transplantation, the limited availability of limbal tissue particularly in cases of bilateral disease has necessitated the use of alternative tissue sources. In our study, autologous conjunctiva was used as a source of epithelial SCs for transplantation in cases of bilateral disease, and successful outcomes were reported in seven $(78 \%)$ out of nine patients, unexpectedly higher than the $43 \%$ success rate for cells of limbal origin (Figure 2B). Although these results did not reach significance, the higher success rates in patients receiving conjunctival compared with limbal cells could be attributable to the slightly larger biopsies that were obtained from conjunctival tissue. Larger biopsies were harvested from the conjunctiva as there was no risk of inducing SC failure in the donor eye. Notably, this explanation is purely speculative as conjunctival cells in culture did not grow faster than the limbal equivalents and there are no published reports indicating that cells from larger biopsies are associated with improved 
patient outcomes. Additionally, it has been demonstrated that detachment of limbal explants from their scaffolds results in unsuccessful primary cultures [33], potentially explaining the failure of cell growth from limbal explants in cases 5 and 12 .

In $25 \%$ of our patients, cells failed to grow from explants and a second set of biopsies was harvested before successful ex vivo expansion. Although many studies do not disclose the number of detachments, Sangwan and colleagues [31] (2011) reported successful cellular growth from tissue explants in all 200 eyes when cultured on HAM, suggesting that a synthetic CL scaffold may not be as effective as a native substrate for expansion. The ability to make direct comparisons with their study, however, is hindered by the heterogeneity of disease. Whereas patients in the study by Sangwan and colleagues were diagnosed with unilateral ocular surface burns, $44 \%$ of the patients in the present study had bilateral LSCD and many cases also had had previous surgeries to the donor eye, potentially impacting the proliferative capacity of harvested cells. Additionally, the culture technique of Sangwan and colleagues, which involved shredding presumably larger segments of donor limbal tissue into small pieces and explanting these over the substrate, could have contributed to the higher success rate of their culture system. Regardless, our study addresses the challenge of biopsy detachment since multiple autologous samples were obtained and the CL substrate is easily available, allowing more than one culture to be initiated with minimal difficulties.

In relation to lineage origin, the conjunctival epithelium is perhaps the cell type most closely related to the corneal epithelium [34]. Kawasaki and colleagues [35] found a population of keratin-12-positive cells in the conjunctival epithelium, presumed to be ectopically residing corneal epithelial cells. Additionally, Majo and colleagues [36] discovered that porcine corneal and conjunctival holoclones shared an ocular gene expression profile, supporting our proposition that conjunctival and limbal epithelial cells can be interchanged. Notably, their results have raised controversy on multiple levels; however, they noted two differentially expressed genes between these epithelia from over 20,000 assessed. Although the precise mechanisms of how conjunctival cells re-establish the ocular surface are not known, the conjunctiva contain its own SCs that may have the ability to transdifferentiate when exposed to corneal-specific signals $[37,38]$. For example, Shapiro and colleagues [39] found that, after 4 to 5 weeks, transplanted conjunctival epithelial cells morphologically resembled corneal epithelium. It should be noted, however, that these findings are controversial, and subsequent studies showed that transplanted conjunctival cells retained lineage-specific features [40,41]. Despite this, transplanted conjunctival epithelium has been shown to successfully regenerate the ocular surface in rabbit models of total LSCD [38,42,43] as well as in patients with LSCD [44-46]. Notably, end-stage limbal stem cell failure is characterised by conjunctivalisation of the ocular surface. However, the conjunctival cells transferred in our study were epithelial in origin, and isolated from an area of conjunctiva that was not affected by disease, which may have accounted for their transparency after engraftment. Further conjunctival epithelial cells alone, without the vascularised conjunctival stroma were utilised for our patients. The present study demonstrates the effectiveness of conjunctival-derived progenitor epithelial cells in transplants, suggesting that even if conjunctival cells do not transdifferentiate, they may acquire a corneal-like phenotype under the culture conditions provided.

Although the primary aim of restoring corneal epithelial integrity and thus resolving ocular discomfort was achieved, improved visual acuity as the secondary outcome measure was attained in $50 \%$ of the successful transplants with at least a one-line improvement in BCVA and 20\% maintaining their pre-operative visual acuity (Table 2). This was attributed to the majority of patients having pre-existing corneal scarring or concomitant ocular disease limiting vision or both. Most (90\%) patients with successful transplants reported complete resolution of their ocular symptoms (burning, photophobia, or discomfort), and one patient (case 11) complained of some (albeit reduced) discomfort, potentially attributable to his coexisting dry eye.

The cause of graft failure in patients with LSCD is poorly understood. $\mathrm{Li}$ and colleagues [47] have recently shown that limbal niche and stromal cells are important in supporting LESCs; thus, damage to the stromal niche microenvironment could contribute to failures in some patients since $\mathrm{SC}$ transfer does not address this anatomical and structural modification. Curiously, we and others [48] observed a higher failure rate in patients with chemical injuries, the cause of which is unknown but could be due to excessive niche damage. Furthermore, of the six failed transplants in our study, four failed within the first 4 months and two eyes failed in the following 1- to 2-year period, both complicated by ocular surface toxicity due to glaucoma medications. Additional investigations are required to determine whether glaucoma medication could be revised prior to and during a specific period post-cell therapy to increase the survival probability of grafts in patients with coexisting severe glaucoma. Indeed, since our study commenced, a wider range of glaucoma medications with less potential for ocular surface toxicity have become available [49].

Minor complications occurred with CL insertion and removal in two patients. In patient 1 , we noted that the CL rolled under the superior lid. However, since our procedure involves harvesting multiple biopsies, a second cell-laden CL was readily available and this was inserted over the patient's cornea the following day. The option of a replacement graft is attractive and advantageous as it reduces the need to re- 
biopsy, re-culture cells, re-schedule the procedure, and delay treatment for the patient. In case 9, a small defect occurred upon removal of the $\mathrm{CL}$ with stripping of superficial corneal epithelial cells; however, this resolved within 24 hours and was not associated with any long-term sequelae. In a third patient (case 2), the biopsy integrated onto the patient's cornea and the transplant was deemed a success at 5.7 years. Retention of the biopsy on the ocular surface was a positive prognostic factor in this patient, but if integration occurred over the visual axis, sight could have been affected. Although it has been recognised that $\mathrm{CL}$ wear can be associated with severe limbal SC failure [24], this occurs with long-term wear; the total time of lens wear in our patients was 2 weeks. Notably, irrespectively of the type of graft, once the lens was removed from the patients' ocular surface, it contained few remnant cell colonies [21].

We acknowledge several limitations of our study. Firstly, our investigation included a small sample size and a heterogeneous patient population. The differing aetiologies, preoperative condition, and concomitant ocular morbidities limit the potential to make direct comparisons with previously published studies [48,50]; however, most reports share similar constraints. Furthermore, with the exception of the case report by Ang and colleagues [51], who compared the efficacy of conventional and cultivated LSCT, almost no direct comparative studies for LSCT in human subjects have been published. It is worth noting that success rates differ significantly between patient groups with different aetiologies of LSCD and that further studies investigating specific patient subtypes could reveal, for example, particular effectiveness of CL delivery for patients with iatrogenic-induced LSCD. Furthermore, we included both total and partial LSCD as patients in both groups had failed prior therapy. Ideally, a control group should have been included; however, owing to the severity and progressive nature of LSCD, it is unethical not to treat these patients. The lack of a standardised framework for the diagnosis and grading of LSCD is also a limitation of our study and is a major concern of most published work in this field [50,52]. An alternative objective scoring system could be developed on the basis of impression cytology. However, this procedure has not been routinely performed in clinical trials of LSCD [50] as it does not significantly change the clinical diagnosis and exposes patients to unnecessary pain and the risk of developing epithelial defects [10]. Symptom-based questionnaires are also flawed in the subjectivity of self-reporting and have not been validated for patients with LSCD. Another limitation of the present study is the inability to directly trace the fate of transplanted cells. The mechanism by which SC transplantation regenerates the corneal epithelium is not well understood, and there is controversy surrounding whether transplanted cells actually replenish the SC reserve or revive any remaining quiescent SCs $[10,29]$. To address these critical questions, one could perform genetic lineage tracing
[53] but these studies would need to be performed in laboratory animals, whereby marked SCs from transgenic mice could be transplanted into wild-type recipients and their long-term fate and function determined. We have made progress in this area and recently established a unique transgenic model whereby progenitor cells and their progeny are traceable in live mice in real time [54].

The strengths of our study include its prospective nature and length of follow-up. Our current findings substantiate our earlier report [21] and confirm that SCs transplanted via our novel $\mathrm{CL}$ delivery technique are maintained for longer than 1 year, and successful outcomes were recorded at a maximum follow-up of 5.8 years. The greatest advantage of our approach is its autologous xeno-free nature and the benefits in cost-effectiveness and accessibility over other transplantation strategies. Additionally, CLs have been shown to adsorb growth factors from serum and may act as a slow-release device for SC-promoting factors at least during the implantation period $[55,56]$. Recently, surface modifications to CL polymers were demonstrated to enhance the loading and transfer capacity of corneal epithelial cells to wounded rabbit corneas $[19,20]$.

\section{Conclusions}

In this study, we have shown that our technique of ocular surface epithelial SC transplantation is a viable and promising alternative to current approaches, successfully regenerating a healthy ocular surface in patients with LSCD at short- to mid-term follow-up in $63 \%$ of our patients. This is consistent with similar studies using alternative transplantation methodologies but our technique does not expose the grafts to foreign human biological or xenogeneic materials.

\section{Abbreviations}

BCVA: best corrected visual acuity; $\mathrm{CL}$ : contact lens; HAM: human amniotic membrane; HREC: Human Research Ethics Committee; LESC: Iimbal epithelial stem cell; LSCD: limbal stem cell deficiency; LSCT: limbal stem cell

transplantation; PED: persistent epithelial defect; SC: stem cell; SESLHD: South Eastern Sydney Local Health District Human Research Ethics Committee.

\section{Competing interests}

The authors declare that they have no competing interests.

\section{Authors' contributions}

SB participated in conception and design of the study, collection and assembly of data, data analysis and interpretation, and manuscript writing SW and ND participated in conception and design of the study, provision of study material or patients, collection and assembly of data, data analysis and interpretation, and manuscript writing. SC participated in collection and assembly of data and data analysis and interpretation. All authors read and approved the final manuscript.

\section{Authors' information}

SW and ND are equal senior authors.

\section{Acknowledgements}

Written informed consent was obtained from the patients for publication of their individual details in this article. The consent form is held by the authors and is available for review by the Editor-in-Chief. Funding was provided by a University of New South Wales GoldStar Award to ND, the Australian Stem Cell Centre Strategic Development Fund, and the Brian Kirby Foundation and by a 
National Health and Medical Research Council Practitioner Fellowship (ID 394000) and a Career Development Fellowship for SW (APP1050524). The funding organisations had no role in the design or conduct of this research.

\section{Author details}

${ }^{1}$ School of Medical Sciences, University of New South Wales, High Street, Kensington, Sydney 2052, Australia. ${ }^{2}$ Save Sight Institute, University of Sydney, 8 Macquarie Street, Sydney 2000, Australia. ${ }^{3}$ Sydney Eye Hospital, 8 Macquarie Street, Sydney 2000, Australia. ${ }^{4}$ Faculty of Medicine, University of New South Wales, High Street, Kensington, Sydney 2052, Australia.

\section{Received: 24 September 2014 Revised: 10 December 2014} Accepted: 17 February 2015 Published online: 12 March 2015

\section{References}

1. Cotsarelis G, Cheng S-Z, Dong G, Sun T-T, Lavker RM. Existence of slow-cycling limbal epithelial basal cells that can be preferentially stimulated to proliferate: implications on epithelial stem cells. Cell. 1989;57:201-9.

2. Dua $H$, Joseph $A$, Shanmuganathan $V$, Jones RE. Stem cell differentiation and the effects of deficiency. Eye. 2003;17:877-85.

3. Kenyon KR, Tseng S. Limbal autograft transplantation for ocular surface disorders. Ophthalmology. 1989;96:709-22.

4. Baylis O, Figueiredo F, Henein C, Lako M, Ahmad S. 13 years of cultured limbal epithelial cell therapy: a review of the outcomes. J Cell Biochem. 2011;112:993-1002.

5. Shimazaki J, Aiba M, Goto E, Kato N, Shimmura S, Tsubota K. Transplantation of human limbal epithelium cultivated on amniotic membrane for the treatment of severe ocular surface disorders. Ophthalmology. 2002;109:1285-90.

6. Utheim TP. Limbal epithleial cell therapy: past, present, and future. Methods Mol Biol. 2013;1014:3-43.

7. Touhami A, Grueterich M, Tseng SC. The role of NGF signaling in human limbal epithelium expanded by amniotic membrane culture. Invest Ophthalmol Vis Sci. 2002;43:987-94.

8. Levis H, Daniels JT. New technologies in limbal epithelial stem cell transplantation. Curr Opin Biotechnol. 2009;20:593-7.

9. Hao Y, Ma DH-K, Hwang DG, Kim WS, Zhang F. Identification of antiangiogenic and antiinflammatory proteins in human amniotic membrane. Cornea. 2000;19:348-52

10. Rama P, Matuska S, Paganoni G, Spinelli A, De Luca M, Pellegrini G. Limbal stem-cell therapy and long-term corneal regeneration. N Engl J Med. 2010;363:147-55

11. Zakaria N, Koppen C, Van Tendeloo V, Berneman Z, Hopkinson A, Tassignon $\mathrm{M}-\mathrm{J}$, et al. Standardized limbal epithelial stem cell graft generation and transplantation. Tissue Eng Part C Methods. 2010;16:921-7.

12. Chirila TV, Barnard Z, Harkin DG, Schwab IR, Hirst LW, et al. Bombyx mori silk fibroin membranes as potential substrata for epithelial constructs used in the management of ocular surface disorders. Tissue Eng Part A. 2008;14:1203-11.

13. Liu J, Lawrence BD, Liu A, Scwab IR, Oliveira LA, Rosenblatt MI, et al. Silk fibroin as a biomaterial substrate for corneal epithelial cell sheet generation. Invest Ophthalmol Vis Sci. 2012;53:4130-8.

14. Dravida S, Gaddipati S, Griffith M, Merrett K, Madhira SL, Sangwan VS, et al. A biomimetic scaffold for culturing limbal stem cells: a promising alternative for clinical transplantation. J Tissue Eng Regen Med. 2008;2:263-71.

15. Galal A, Perez-Santonja JJ, Rodriguez-Prats JL, Marta A, Jorge A, et al. Human anterior lens capsule as a biologic substrate for the ex vivo expansion of limbal stem cells in ocular surface reconstruction. Cornea. 2007;26:473-8.

16. Di Girolamo N, Chui J, Wakefield D, Coroneo MT. Cultured human ocular surface epithelium on therapeutic contact lenses. $\mathrm{Br}$ J Ophthalmol. 2007:91:459-64.

17. Deshpande P, Notara M, Bullett N, Daniels JT, Haddow DB, MacNeill S. Development of a surface-modified contact lens for the transfer of cultured limbal epithelial cells to the cornea for ocular surface diseases. Tissue Eng Part A. 2009;15:2889-902.

18. Gore A, Horwitz V, Gutman H, Tveria L, Cohen L, Cohen-Jacob O, et al. Cultivation and characterization of limbal epithelial stem cells on contact lenses with a feeder layer: toward the treatment of limbal stem cell deficiency. Cornea. 2013:33:65-71.

19. Zhang H, Brown KD, Lowe PS, Liu G-S, Steele D, Abberton K, et al. Acrylic acid surface-modified contact lens for the culture of limbal stem cells. Tissue Eng Part A. 2014;20:1593-602.
20. Brown KD, Low S, Mariappan I, Abberton KM, Short R, Zhang H, et al. Plasma polymer-coated contact lenses for the culture and transfer of corneal epithelial cells in the treatment of limbal stem cell deficiency. Tissue Eng Part A. 2014;20:646-55.

21. Di Girolamo N, Bosch M, Zamora K, Coroneo MT, Wakefield D, Watson S. A contact lens-based technique for expansion and transplantation of autologous epithelial progenitors for ocular surface reconstruction. Transplantation. 2009;87:1571-8.

22. Deshpande P, Ramachandran C, Sefat F, Mariappan I, Johnson C, McKean R, et al. Simplifying corneal surface regeneration using a biodegradable synthetic membrane and limbal tissue explants. Biomaterials. 2013;34:5088-106.

23. Rama P, Bonini S, Lambiase A, Golisano O, Paterna P, De Luca M, et al. Autologous fibrin- cultured limbal stem cells permanently restore the corneal surface of patients with total limbal stem cell deficiency. Transplantation. 2001;72:1478-85.

24. Chan C, Holland EJ. Severe limbal stem cell deficiency from contact lens wear: patient clinical features. Am J Ophthalmol. 2013;155:544-9.

25. Dua HS, Azuara-Blanco A. Limbal stem cells of the corneal epithelium. Surv Ophthalmol. 2000;44:415-25

26. Eidet JR, Fostad IG, Shatos MA, Utheim TP, Utheim OA, Raeder S, et al. Effect of biopsy location and size on proliferative capacity of ex vivo expanded conjunctival tissue. Invest Ophthalmol Vis Sci. 2012;53:2897-903.

27. Fostad IG, Eidet JR, Shatos MA, Utheim TP, Utheim OA, Raeder $\mathrm{S}$, et al. Biopsy harvesting site and distance from the explant affect conjunctival epithelial phenotype ex vivo. Exp Eye Res. 2012;104:15-25.

28. Santos MS, Gomes JA, Hofling-Lima AL, Rizzo LV, Romano AC, Belfort R. Survival analysis of conjunctival limbal grafts and amniotic membrane transplantation in eyes with total limbal stem cell deficiency. Am J Ophthalmol. 2005;140:223-30.

29. Pellegrini G, Rama P, Matuska S, Lambiase A, Bonini S, Pocobelli A, et al. Biological parameters determining the clinical outcome of autologous cultures of limbal stem cells. Regen Med. 2013;8:553-67.

30. Shimazaki J, Higa K, Morito F, Dogru M, Kawakita T, Satake Y, et al. Factors influencing outcomes in cultivated limbal epithelial transplantation for chronic cicatricial ocular surface disorders. Am J Ophthalmol. 2007;143:945-53.

31. Sangwan VS, Basu S, Vemuganti GK, Sejpal K, Subramaniam SV, Bandyopadhyay S, et al. Clinical outcomes of xeno-free autologous cultivated limbal epithelial transplantation: a 10-year study. Br J Ophthalmol. 2011;95:1525-9.

32. Basu S, Ali H, Sangwan VS. Clinical outcomes of repeat autologous cultivated limbal epithlieal transplantation for ocular surface burns. Am J Ophthalmol. 2012;153:643-50.

33. Di lorio E, Ferrari S, Fasolo A, Bohm E, Ponzin D, Barbaro V. Techniques for culture and assessment of limbal stem cell grafts. Ocul Surf. 2010;8:146-53.

34. Koroma BM, Yang JM, Sundin OH. The Pax-6 homeobox gene is expressed throughout the corneal and conjunctival epithelia. Invest Ophthalmol Vis Sci. 1997;38:108-20.

35. Kawasaki S, Tanioka H, Yamasaki K, Yokoi N, Komuro A, Kinoshita S. Clusters of corneal epithelial cells reside ectopically in human conjunctival epithelium. Invest Ophthalmol Vis Sci. 2006;47:1359-67.

36. Majo F, Rochat A, Nicolas M, Jaoude GA, Barrandon Y. Oligopotent stem cells are distributed throughout the mammalian ocular surface. Nature. 2008;456:250-4.

37. Pellegrini G, Golisano O, Paterna P, Lambiase A, Bonini S, Rama P, et al. Location and clonal analysis of stem cells and their differentiated progeny in the human ocular surface. J Cell Biol. 1999;145:769-82.

38. Wei Z-G, Wu R-L, Lavker RM, Sun T-T. In vitro growth and differentiation of rabbit bulbar, fornix, and palpebral conjunctival epithelia. Implications on conjunctival epithelial transdifferentiation and stem cells. Invest Ophthalmol Vis Sci. 1993;34:1814-28.

39. Shapiro M, Friend J, Thoft R. Corneal re-epithelialization from the conjunctiva. Invest Ophthalmol Vis Sci. 1981;21:135-42.

40. Wei ZG, Sun TT, Lavker RM. Rabbit conjunctival and corneal epithelial cell belong to two separate lineages. Invest Ophthalmol Vis Sci. 1996:37:523-33.

41. Moyer PD, Kaufman AH, Zhang Z, Kao CWC, Spaulding AG, Kao WWY. Conjunctival epithelial cells can resurface denuded cornea, but do not transdifferentiate to express cornea-specific keratin 12 following removal of limbal epithelium in mouse. Differentiation. 1996;60:31-8.

42. Ang LP, Tanioka H, Kawasaki S, Ang LPS, Yamasaki K, Do TP, et al. Cultivated human conjunctival epithelial transplantation for total limbal stem cell deficiency. Invest Ophthalmol Vis Sci. 2010;51:758-64. 
43. Jeon S, Choi SH, Wolosin JM, Chung S-H, Joo C-K. Regeneration of the corneal epithelium with conjunctival epithelial equivalents generated in serum-and feeder-cell-free media. Mol Vis. 2013;19:2542-50.

44. Tanioka H, Kawasaki S, Yamasaki K, Ang LPK, Koizumi N, Nakamura T, et al. Establishment of a cultivated human conjunctival epithelium as an alternative tissue source for autologous corneal epithelial transplantation. Invest Ophthalmol Vis Sci. 2006;47:3820-7.

45. Dogru M, Tsubota K. Survival analysis of conjunctival limbal grafts and amniotic membrane transplantation in eyes with total limbal stem cell deficiency. Am J Ophthalmol. 2005;140:305-6.

46. Ricardo JRS, Cristovam PC, Filho PAN, Farias CC, de Araujo AL, Loureiro RR, et al. Transplantation of conjunctival epithelial cells cultivated ex vivo in patients with total limbal stem cell deficiency. Cornea. 2013;32:221-8.

47. Li Y, Inoue T, Takamatsu F, Kobayashi T, Shiraishi A, Maeda N, et al. Differences between niche cells and limbal stromal cells in maintenance of corneal limbal stem cells. Invest Ophthalmol Vis Sci. 2014;13:1453-62.

48. Zakaria N, Possemiers T, Dhubhghaill SN, Leysen I, Rozema I, Koppen C, et al. Results of a phase I/II clinical trial: standardized, non-xenogenic, cultivated limbal stem cell transplantation. J Transl Med. 2014;12:58.

49. Lockington D, MacDonald ECA, Stewart P, Young D, Caslake M, Ramaesh K. Free radicals and the $\mathrm{pH}$ of topical glaucoma medications: a lifetime of ocular chemical injury? Eye. 2012;26:734-41.

50. Shortt AJ, Secker GA, Notora MD, Limb GA, Khaw PT, Tuft SJ, et al. Transplantation of ex vivo cultured limbal epithelial stem cells: a review of techniques and clinical results. Surv Ophthalmol. 2007;52:483-502.

51. Ang LP, Sotonzo C, Koizumi N, Suzuki T, Inatomi T, Kinoshita S. A comparison between cultivated and conventional limbal stem cell transplantation for Stevens-Johnson syndrome. Am J Ophthalmol. 2007;143:178-80

52. Harkin DG, Apel AJ, Di Girolamo N, Watson S, Brown K, Daniell MD, et al. Current status and future prospects for cultured limbal tissue transplants in Australia and New Zealand. Clin Exp Ophthalmol. 2013;41:272-81.

53. Kretzschmar K, Watt FM. Lineage tracing. Cell. 2012;148:33-45.

54. Di Girolamo N, Bobba S, Raviraj V, Delic NC, Slapetova I, Nicovich PR, et al. Tracing the fate of limbal epithelial progenitor cells in the murine cornea. Stem Cells. 2015;33:157-69.

55. Echevarria TJ, Chow S, Watson S, Wakefield D, Di Girolamo N. Vitronectin: a matrix support factor for human limbal epithelial progenitor cells. Invest Ophthalmol Vis Sci. 2011;52:8138-47.

56. Chow S, Di Girolamo N. Vitronectin: a migration and wound healing factor for human corneal epithelial cells. Invest Ophthalmol Vis Sci. 2014:55:6590-600.

\section{Submit your next manuscript to BioMed Central and take full advantage of:}

- Convenient online submission

- Thorough peer review

- No space constraints or color figure charges

- Immediate publication on acceptance

- Inclusion in PubMed, CAS, Scopus and Google Scholar

- Research which is freely available for redistribution 